DOI 10.31558/2075-2970.2018.35-36.10

УДК $811.124 * 373$

(C) Т. М. Компанець

(Вінниця)

\title{
ВЕРБАЛЬНІ ЗАСОБИ ВТІЛЕННЯ ПРИРОДНИЧОГО ФРАГМЕНТУ АНТИЧНОЇ КАРТИНИ СВІТУ
}

У статті крізь призму когнітивного підходу досліджуються фрагменти концептуальної та мовної картин світу латиномовного соціуму Давнього Риму. Визначена роль міфологічного світосприйняття як суттєвого чинника концептуалізації природничих реалій. На основі аналізу окремих іменників-дендронімів виявлені особливості мовного членування навколишнього світу відповідно до рівня природознавчих уявлень античних народів. Встановлені лексикосемантичні ознаки латиномовного природничого фрагменту античної картини світу.

Ключові слова: концепт, концептуальна і мовна картини світу, національна ментальність, класичні мови, міфологічна свідомість, лексика, дендроніми.

Актуальність дослідження мовних картин світу віддалених епох зумовлена потребою осмислення рецепції античної спадщини, зростанням інтересу до концептуальних та вербальних моделей картини світу, які переймають на себе функції збереження національної ідентифікації та духовно-культурних пріоритетів. Відповідно лексичний ресурс класичних мов усвідомлюється не тільки як основа античної ментальності та греко-латинських концептів, а і в подальшому сприймається як міцне підгрунтя для сучасних надбань і досягнень.

Метою запропонованої статті є аналіз складників структури мовної картини світу, що відобразилася в латинській природничій лексиці, а саме у дендронімах (назвах дерев), у координатах бачення об'єктивної реальності.

Для досягнення поставленої мети передбачено розв'язання таких завдань:

1) реконструювати фрагмент первісного стану античної картини світу;

2) визначити сутнісні характеристики лінгвістичних основ картини світу, яка перебуває у тісному зв'язку з природознавчими уявленнями стародавніх римлян;

3) дослідити семантичні особливості латинських назв вічнозелених дерев, як безпосереднього складника вербальної моделі античної картини світу;

4) проаналізувати культурно маркований зміст у семантиці мовних одиниць.

Об'єкт дослідження - латинська природнича лексика як той мовний рівень, який тісно пов'язаний із позамовною реальністю і найдинамічніше відбиває світобачення народу, у тому числі і на віддалених хронологічних зрізах. Увагу зосереджено на тих лексичних одиницях, які визначають специфіку античного мовно-культурного простору й передають ключові по- 
няття (концепти) латиномовної картини світу. Таким чином, когнітивна спрямованість назв дерев як засобу імплікації знань про світ, авторські інтенції (тобто інтенції представників народу-носія мови), щодо поданого сегменту лексики, постають предметом аналізу.

Основне джерело матеріалу - писемні пам'ятки класичного періоду латинської мови: «Naturalis Historia» («Природнича історія») римського енциклопедиста Плінія Старшого, поеми Вергілія «Bucolica» («Буколіки») та «Georgica» («Георгіки»), а також уривки із прозаїчних i поетичних творів інших латинських авторів на природничу тематику. Враховано дані, які містяться в лексикографічних джерелах (Дворецкий 2000, Totius Latinitatis Lexicon 1858-1875; Ernout, Meillet 1910; Walde 1910). Залучення творів римських письменників дає підстави чіткіше охарактеризувати індивідуально-авторську картину світу, а у словниках різних типів відображена специфіка семантизації концептів, подаються особливості «внутрішньої» форми слова та максимальна вербальна репрезентація концептуальної сфери.

Концепт - одне з ключових понять сучасного мовознавства. Проблеми дефініції концепта були в центрі уваги визначних вітчизняних і зарубіжних лінгвістів: Н. Д. Арутюнової, С. О. Аскольдова-Алєксєєва, А. Вежбицької, Л. С. Вигодського, Д. С. Ліхачова, О. О. Потебні, Ю. С. Степанова. У працях більшості учених категорія «концепт» нерозривно пов'язана 3 поняттям «картина світу», під яким розуміють насамперед глобальний, всеохоплюючий образ світу, який є результатом усієї духовної активності людини. Класичним (з лінгвокультурологічних позицій) стало визначення концепту, запропоноване Ю. С. Степановим: «Концепт - це ніби згусток культури у свідомості людини; те, у вигляді чого культура входить у ментальний світ людини; ... те, через посередництво чого людина сама входить в культуру, а у деяких випадках і впливає на неї, ... той пучок уявлень, понять, знань, асоціацій, який супроводжує слово» (Степанов, 2001, с. 43). Разом з тим зазначимо, що серед мовознавців утвердилася думка про обмежену кількість концептів. Концептами виступають лише ті лексеми, що сприймаються свідомістю як актуальні і знакові, мають велику кількість одиниць для своєї фіксації, відображені у фразеологічному фонді, художніх дефініціях і постають носіями культурної пам'яті народу. Концепт має складну структуру: до неї входить все, що має відношення до структури поняття, а також те, що робить концепт «фактом культури - вихідна форма (етимологія); стисла до основних ознак історія; різноманітні асоціації та оцінки». Отже, концепт являє собою «основний осередок культури у ментальному світі людини» (Степанов, 2001, с. 43).

Людина і природа - дві основні сутності цього світу, що нерозривно пов'язані між собою. Із самого початку все життя і діяльність людини - це пізнання оточуючого світу, взаємодія з природою у всій різноманітності ï форм і проявів. Рання архаїка - період, коли навіть у 
соціальній структурі визначальне значення мали родові («природні») стосунки, коли людина не відділяла себе від природи і сприймала ії саме як природу - всесвіт, універсум. Римський поет Вергілій у поемі «Георгіки», одухотворюючи світ природи, по-філософському стверджував: Hoc natura modos primum dedit, // Sivarum fruticumque viret nemorumque sacrorum (Verg. Georg. 2.20). 'Так природой самой устроено, чтобы зеленели, // Всякого рода леса, и кусты, и священные рощи’ (Пер. С. Шервинского) (Вергилий, 1971, с. 78).

Середземноморська флора в античні часи відзначалася багатством і величезним різноманіттям, тому обмежуючи матеріал, в центрі нашої уваги - назви на позначення хвойних вічнозелених дерев, що перебрали на себе статус концептів: сосна, кедр, ялина, тис.

Вічна зелень, хвойність, приємний бальзамічний запах цілої низки дерев втілювали життєдайність, нездоланну силу, символізували вічність, безсмертя, постійність і наполегливість.

Проаналізований лексичний матеріал дає підстави стверджувати, що на позначення нев’янучих, вічнозелених дерев, трави, кущів у латинській мові не було окремого слова, яке б об’єднало ці природні реалії на основі спільної семантики «вічнозелений». Натомість, серед дериватів, утворених від дієслова vireo, ere ‘бути зеленим, зеленіти’ знаходимо партиципіальні утворення sempervirens, perpetuo virens: cedrus - arbor perpetuo virens (Forcell., t. 2, p. 129) ‘кедр - вічнозелене дерево'. Римські автори засвідчують, що на віллах багатих римлян в одному із внутрішніх двориків обов'язково знаходився сад вічнозелених дерев viridiarium (Plin. N.H 18.2.1; Cic .2. Att. 3), що символізував багатство, могутність, самовпевненість і нездоланні сили. Viridiarium - локативний іменник, утворений за допомогою суфікса -arium від прикметника viridis 'зелений'. Латинські лексикографічні джерела пояснюють значення іменника viridiarium наступним чином: est locus virentibus arboribus herbisque amoenus (Forcell.,t. 6, p. 355) - 'вірідіарій - це місце приємне зеленими деревами і травами'. Священна зелень, ніжне листя і молоді гілки вічнозелених дерев - лавра, маслини, мирта - verbenae відігравали важливу роль в духовному житті римлян. Verbenae носили на голові феціали (римські жерці) під час проведення переговорів з приводу порушення домовленостей, проголошення війни чи укладання миру.

Історично першою формою світоглядної свідомості, в межах якої сформувалася розгорнута картина світу, була міфологічна свідомість. Основні напрямки інтерпретації міфу, а саме символізм, алегоризм, евгемеризм, започаткувалися у класичну давнину. Так, Платон уявляв міфологію як символічне змалювання оточуючого середовища (ФЭС, 1997, с. 343-344). Софісти і стоїки під міфом розуміли моральні сентенції, які виражалися символами і алегоріями, 
а Евгемер, абстрагуючись від усього надприроднього, бачив у міфах розповіді про реальні події (ФЭС, 1997, с. 437).

Античні традиції сприйняття міфології продовжилися у пізніших трактуваннях учених. Міфологія, на думку О. О. Потебні, «є історія міфічного світогляду, у чому він би не втілювався: у слові і сказанні, або матеріальному пам'ятнику, звичаї та обряді» (Потебня, 1976, c. 426). О. М. Фрейденберг вважає, що називати міфом лише словесно виражену оповідь було б найчистішою умовністю: «насправді таким же міфом служать і дії, і речі, і мова, і побут первісної людини, тобто вся ії свідомість і все те, що спрямовано на цю свідомість» (Фрейденберг, 2008, с. 28). Буття картини світу у мові інтерпретується як існування одиниць у синтагматиці та парадигматиці, тексті і системі. «Міфологія як засіб глобального концептування, зазначає Д. С. Раєвський, - немислима поза парадигматичним аспектом, поза нерозривною єдністю міфологічної оповіді (сюжетів, подій) і міфологічних уявлень (світосприйняття, міфічної картини світу)» (Раевский, 1985, с. 22).

Cedrus (Cedrus libani L.) кедр - хвойне вічнозелене дерево, один із найстаріших видів рослин на планеті. Про великі кедрові ліси згадується в епосі давніх шумерів за тисячу років до нашої ери. Дерево вирощували тільки великі боги, а в раю кедр ріс ще до створення світу. Відповідно до сказання, коли перших людей вигнали з раю, то Адам взяв із собою кілька зерняток дерев. Серед них були кедр, сосна і кипарис, саме ці дерева дали життя першим деревам на землі. Найшанованіші та найвпливовіші грецькі і римські боги та герої увічнювалися в бюстах із кедрової деревини. Римські імператори, намагаючись зберегти кедрові гаї для своїх власних потреб, прикріплювали на деревах таблички з написом proprietas senatus populique Romani ‘власність сенату і римського народу'. Кедр в античній ментальності символізував владу і міць, повноцінність буття і в той же час уособлював гордість і зарозумілість. У прагматичному аспекті деревина кедра використовувалася античними народами для спорудження храмів богів і палаців правителів, саркофагів єгипетських фараонів.

Латинська лексема cedrus (Vitr. 2.9.13; Ovid. Am. I.14.12; Plin. N.H 12.125; Verg. Georg. 3.414 ) використовувалася на позначення як дерева, так і смоли. На той час римському натуралісту Плінію було відомо про два види дерева: лідійське і фінікійське duo eius genera, Lycia et Phoenicia (Plin. N.H 13.52). Друге значення cedrus ‘благовоніє духмяна смола, яку отримували із кедра з ритуальною метою'. У латинській мові cedrus запозичено з грецької, де фіксується 3 часів Гомера (Одіссея, VIII). Етимологічні джерела практично одностайні, позначаючи слово як невідомого середземноморського походження, можливо фінікійського (Ernout, Meillet, 1910, c. 196). Рефлекси латино-грецького cedrus знаходимо у більшості сучасних мов Європи: 
англ. cedar, нім. Zeder; фр. сеdre, ісп., іт., порт. сеdro; польс. cedr; укр., рос. кедр, болг. кедър, серб. кедар.

Одне із найкрасивіших дерев середземноморських тропіків - італійська сосна, пінія (Pinus pinea L) згадується в міфах про Діану, Кібелу, бога морів Посейдона. Пінія вважалася улюбленим деревом одного із самих життєрадісних богів античного світу козлоногого Пана. За легендою дерево отримало назву від імені німфи Пітіс. Палко покохала Пітіс веселого пустотливого Пана. Але це кохання викликало великі ревнощі у Борея, бога холодного північного вітру. Із ревнощів Борей перетворив німфу на красиве вічнозелене дерево на ім'я Пітіс, а Пана часто зображали із сосновим вінком на голові.

У латинській мові серед групи найменувань вічнозелених хвойних дерев лексема pinus (Ov. Met. 14.637; Fast. 1.412; Plin. N.H 16.33.1; Verg. Georg. 389; Ecl. 7.65; Hor. Epod.16.57) займає особливе місце. Пінія була окрасою римських садів, про що знаходимо підтвердження у 7-й еклозі Вергілія: Fraxinus in silvis pulcherrima, pinus in hortis, // Populus in fluviis, abies in montis altis (Verg Ecl. 7.65) 'ясен - найкрасивіший у лісах, пінія - у садах, тополя - біля річок, ялина - у високих горах’. Багато лінгвістів сходяться на думці, що це слово збереглося в італійській мовній гілці з періоду спільноіндоєвропейської мовної єдності.

Давні мовознавці намагалися пояснити походження лексеми pinus, виходячи з ментального сприйняття світу природи, формуючи у такий спосіб «народну етимологію». У даному випадку базисом для тлумачення походження слова стала особливість колючого гілля. Pinus nomen arboris picae, ita ab acumine foliorum vocatae; pinum etiam antique acutum nominadant (Isid. 17. Orig. 7.31) 'пінія - назва соснового дерева, (воно) так назване через гострі кінчики листя; пінію в старовину також називали колючкою' (Totius Latinitatis Lexicon 1875, t. IV: 679).

Щодо сучасних тлумачень походження слова pinus, то автори етимологічних словників латинської мови приходять до висновку, що можна вважати спорідненими pinus 'сосна', i pituita - 1) ‘сік, який витікає із просвердленого стовбура дерева'; 2) ‘слиз', 'мокротиння’ (Ernout, Meillet, 1910, с. 901; Walde, 1910, с. 585). Ботанічне значення слова pituita Пліній пояснює так: fungorum origo non nisi ex pituita arborum (Plin. N.H 22.47.1) 'щодо походження губчатого наросту, то це є ніщо інше, як 'сік дерева'. Катон подає медичне значення терміна pituita 'слиз', 'мокротиння', 'нежить' (Cato. Agr. 156.4). Отже, латинське pinus, а також давньогрецьке гомерівське $\pi \imath v \varsigma$ 'сосна' та pituita ‘слиз', ‘мокротиння' походять від і.-є. *pitu-daru - що може означати ‘дерево, що виділяє рідину, смолу’, де перша складова *pitu - трактується у значенні 'рідина', 'смола'. На думку П. Фрідріха, в середземноморському ареалі до споріднених латин-

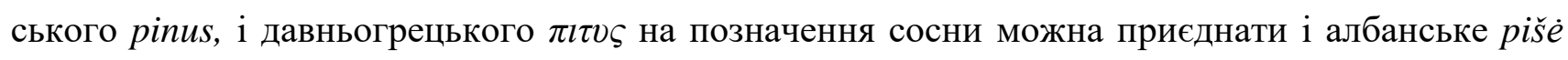


‘ялина', 'сосна' (Friedrich, 1970, с. 53). Т. В. Гамкрелідзе і В’яч. Вс. Іванов, досліджуючи походження назв вічнозелених хвойних дерев у індоєвропейських мовах, підкріплюють проаналізовані приклади памірським рit 'ялиця' і роблять висновок про те, що 'діалектний розподіл співвідносних слів (греко-арійський, італійський, албанський) засвідчують спільно-індоєвропейський характер основи $* p^{[h]} i t^{[h]}$ у значенні 'сосна','ялиця' (Гамкрелидзе, Иванов, 1984, с. 631). За семантичною подібністю до проаналізованої лексичної одиниці слід віднести латинське picea (Plin. N.H 16.18.1; 19.3; Verg. Georg. 2.438; 3.450; Aen. 9.87) 'сосна звичайна' або 'шотландська' (Pinus silvestris L). Про особливості цього дерева знаходимо пояснення насамперед у Плінія: Picea montes amat atque frigora (Plin. N.H 16.40) 'сосна любить гори і холод'. Римський енциклопедист подає таке уточнення: .... situs eius est in excelso montium, sed maria fugerit (Plin. N.H. 19.3) ‘... iï (сосни) місцезнаходження високо в горах, а морів уникає', але найважливіша характеристика, яка має значення для уточнення семантичної характеристики найменування, міститься в рядках: Picea plurimam resinam fundit (Plin. N.H. 16.18.4) 'сосна дає дуже багато глею'. Про смолистість та велику кількість глею дерева рісеа неодноразово засвідчує Вергілій (Verg. Georg. 2.263; 438; 3.450). Отже, можна погодитися з тезою, згідно якої прикметник piceus є ад’єктивним дериватом іменника pix, picis 'смола' і як субстантив picea (scil. arbor 'дерево') вживався на позначення сосни звичайної, а також одного з видів ялини (Дворецкий, 2000, с. 586).

За даними лексикографічних джерел у поетичному дискурсі слово pinus набирало метонімічного значення, а саме предмети і речі, виготовлені із соснової деревини: корабель, весло, факел, вінок. Так, в одній із своїх од Горацій (Hor. Carm. I.14) іменує корабель Pontica pinus 'понтійська сосна' з подальшим уточненням silvae filia nobilis 'дочка благородного лісу'. Порівняймо також у Овідія: medius tua pinus in undis navigat (Ovid. Ars amat. 2.9) 'твій човен (букв. пінія) плаває на відкритих хвилях’. Про значення хвойних дерев у римському господарстві говорять рядки Вергілія: dant alios aliae foetus, dant utile lignum // Navigiis pinus, domibus cedrumque cupressosque (Verg. Georg. 2.440) '(ліси) приносять багато прибутку, дають корисну деревину, для мореплавання - пінію, для будинків - кедр і кипарис'. I у господарстві італіків сосна, як і інші породи дерев, знаходила найрізноманітніше застосування. Так, землероби, щоб уникнути суперечок з сусідами і судових позовів, висаджували на межах своїх ділянок пінії (pinos), кипариси (cupressos), в'язи (ulmos). Порівняємо у Вергілія: ipse thymuт pinosque ftrens de montibus altis // tecta servat late circum (Verg. Georg. 4.112) 'коли чебрець і пінії принесе з високих гір, хай сам їх насаджує (хазяїн) широко навколо житла'. Колумелла свідчить, що деякі породи дерев, у тому числі і сосни (рісеае), годилися для підпірок, до яких прив'язували виноградні лози (Col. R.R. 26,1). 
Про диференційний підхід носіїв латинської мови до сутності конкретних реалій і свідоме вживання відповідних словесних позначень свідчать чітко вмотивовані назви інших вічнозелених дерев відповідно до їх характеристик та функціонального призначення. Карликова сосна, яка відрізнялася тим, що давала велику кількість терпентину (скипидару), який використовувався у тому числі і для смолоскипів, мала назву taeda (Plin. N.H. 16.15; 19.2; Caes. B.G. 3.101; Ovid. Fast. 4.741). Як зазначається у сучасних етимологічних джерелах, слово taeda мало середземноморське походження і було запозичене через етруське посередництво

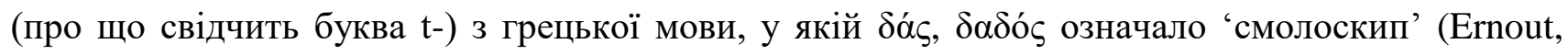
Meillet, 1951, с. 1188). Семантика іменника taeda надавала широкі можливості для метафоричних переходів, а саме: а) ‘смолоскип’; ‘смоляна тріска, що горить, як знаряддя катування’; б) ‘весільний смолоскип'; ‘шлюб, одруження'. Пор. praetendere coniugis taedas 'тримати попереду весільної церемонії шлюбні смолоскипи', переносно 'вступати у законний шлюб' (Дворецкий, 2000, с. 758). Про інщу сосну, яка давала мало смоли і проростала в основному на морських узбережжях, згадує Пліній під назвою tibulus (Plin. N.H. 16.39). Римський автор наводить таке пояснення: Pinaster ... easdem arbores alio nomine esse per oram Italiae, quas tibulos vocant, plerique arbitrantur 'більшість вважає, що pinaster - це ті самі дерева, які під іншою назвою tibulus називають на узбережжі Італії. Ж. Андре супроводжує номінацію tibulus позначкою 'долатинський субстрат' (Andre, 1956, с. 316).

На позначення ялини (Picea abies L.) в латинській мові засвідчена назва abies (Plin. N.H. 16.39; Verg. Georg. 2.68; Aen. 8.91). Намагання середньовічного етимолога Ісидора Сивільського розтлумачити походження дендроніма abies, виходячи із фонетичного збігу з дієсловом ab-eo, ire ‘підноситися’, ‘височіти' на тій підставі, що ялина з поміж інших дерев видається, підноситься у височину, можна віднести до «народної етимології». Пор.: Abies sic appellata, quod prae ceteres arboribus longe eat (h. e abeat) et in excelsum promineat (Isid. 17. Orig. 7.32) 'ялина так названа, через те, що з поміж інших дерев дуже підноситься і видається у височину' (Totius Latinitatis Lexicon 1875, t. 1, с. 11). Сучасні вчені-етимологи не вбачають виваженої аргументаціі у такому поясненні, залишаючи у словниках зазначену лексему з позначкою «3 невідомого середземноморського джерела» та порівнюють латинське abies 3 грецьким

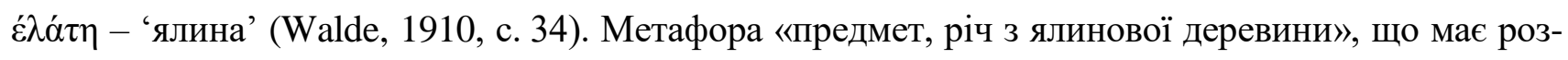
ширену семантику: 1) ‘корабель', 2) 'спис', 3) ‘дощечка для письма' вносить додаткове значення у концептуалізацію поняття abies. Порівняємо у Вергілія : et casus abies visura marinos (Verg. Georg. 2.68) ‘і ялина призначена для того, щоб побачити морські небезпеки’; labitur unda vadis abies (Verg. Aen. 8.91) ‘плине по хвилях просмолена ялина’; longa transverberat abiete pectus (Verg. Aen. 11.667) ‘довгою ялиною (ялиновим списом) проколює груди’. 
Вічнозелене хвойне дерево тис (Taxus baccata L.) не належить до дерев, які б за значущістю могли б репрезентувати флору Апеннінського півострова, але Юлій Цезар у своїх творах неодноразово згадує про великі тисові ліси у Галлії та Германії. Пор.: Taxo, cuius magna in Gallia Germaniaque copia est ... (Caes. B.G. 3.101) 'тис, якого великі запаси є у Галлії і Германії’ ... . Не залишили поза увагою тис Пліній та Вергілій, у творах яких зустрічається дендронім taxus (Plin. N.H. 16.20.1; Verg. Ecl. 9.30). Показово, що обидва римські автори сприймають навколишню природу на рівні тогочасних знань, уявлень і трактувань, через те одностайно засвідчують, що листя і плоди тиса мають отруйні властивості. Так, Пліній говорить, що стріли потрібно змочувати соком тиса, це робило їх більш смертоносними. Більше приділив уваги тису Вергілій, зазначивши, що дерево краще розросталося у холодному кліматі. Пор.: (amat) aquilonem et frigora taxi (Verg. Georg. 2.113) тис (любить) північний вітер і холод’. У іншому місці римський поет стверджує, що тис годився для виготовлення луків: Ituraeos taxi torquentur in arcus (Verg. Georg. 2.448) 'тиси гнулися в ітурійські луки'. Як дбайливий хазяїн Вергілій забороняє насаджувати тиси біля вуликів, бо вважає, що квіти дерева роблять мед гірким: Sic tua Cyrnaeas fugiant examina taxos (Verg. Ecl. 9.30.) 'хай твої рої остерігаються кернійського (корсиканського) тиса' і супроводжує дендронім taxus епітетом nocentes 'шкідливий'. Важлива в аспекті вербалізації архаїчної картини світу лексема taxus з етимологічної точки зору являє собою спірний випадок. На думку одних лінгвістів, латинське taxus співвід-

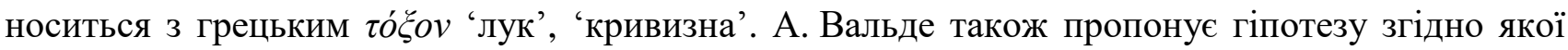
taxus можна вважати похідним словом від д.-і. *tuaksos $i$ порівнює з tvakšah 'сила', tvakš̌̃ $y \bar{a} h$ ‘сильний’ та давньогрецьким бо́коৎ 'щит'. Власне кажучи, тис названий міцним, сильним деревом за властивість деревини не псуватися, опиратися гниттю (Walde, 1910, с. 765). Іншої точки зору дотримуються А. Ерну та А. Мейе, пов’язуючи taxus з прикметником toxicus 'отруйний’ (Ernout, Meillet, 1951, c. 1205).

Проаналізований матеріал дає підстави стверджувати, що семантична структура латинських дендронімів, їх кількість та особливості функціонування віддзеркалюють окремий фрагмент архаїчного світосприйняття, «консервуючи» інформацію про матеріальну культуру та духовний світ античного суспільства. Дендроніми характеризуються під кутом зору відповідності функціональним вимогам. 3 одного боку, простежується чітка прагматика застосування у господарстві деревини, глею, скипідару, ароматизаторів, з іншого боку, вічна зелень, нев’янучість втілювали етичні та моральні цінності, що давало можливість використовувати вінки, гірлянди, корони з вічнозелених дерев з ритуальними і символічними цілями. 
3 генетичної точки зору зазначені лексеми являють собою розмаїту картину, оскільки поряд із словами безперечно індоєвропейського походження, зустрічаються запозичення 3 невідомих давніх мов середземноморського ареалу.

Порівняння корпусу прямих і переносних значень дає можливість стверджувати, що метафоричне вживання дендронімів було властиве, які мислили поетичними образами, що відповідно розширювало і збагачувало мовну картину світу, але з часом поетичний образ бліднув і закріплювався у мові як стерта метафора.

Таким чином, необхідність подальшого дослідження структурування картини світу та іiі субстанціональної сфери не викликає сумнівів.

\section{СПИСОК ЛІТЕРАТУРИ}

1. Блаватский В. Д. Природа и античное общество. М.: Наука, 1976. 87 с.

2. Вежбицкая А. Семантические универсалии и описание языков. М.: Языки русской культуры, 1999. 780 с.

3. Вейсман А. Д. Греческо-русский словарь. СПБ.: Вейсман, 1899. 1368 с.

4. Вергилий. Буколики; Георгики; Энеида / Пер. с лат., вступ. статья М. Г. Гаспарова. М.: Худож. лит., 1971. 540 с.

5. Гамкрелидзе Т .В., Иванов Вяч. Вс. Индоевропейский язык и индоевропейцы: реконструкция и историко-этимологический анализ протоязыка и протокультуры. Тбилиси: Изд-во Тбилисского ун-та, 1984. Ч. 2. 1328 с.

6. Голосовкер Я. Э. Логика мифа. М.: Наука, 1987. 224 с.

7. Дворецкий И. Х. Латинско-русский словарь. 6-е изд., испр. М.: Рус. яз., 2000. 846 с.

8. Колшанский Г. В. Объективная картина мира в познании и языке. М.: Наука, 1990. 107 с.

9. Корнилов О. А. Языковые картины мира как производные национальных менталитетов. М.:ЧеРо, 2003. 349 с.

10. Межжеріна Г. В. Людина в мовній картині часів Київської Русі. К.: Вид. Центр КНЛУ, 2006. 448 с.

11. Потебня А. А. Эстетика и поэтика. М.: Искусство, 1976. 614 с.

12. Раевский Д. С. Модель мира скифской культуры. М.: Наука, 1985. 256 с.

13. Степанов Ю. С. Константы: Словарь русской культуры: изд. 2-е, испр. и доп. М.: Академический проект, 2001. 990 с.

14. Философский энциклопедический словарь / сост. Е. Ф. Губский, Г. В. Кораблева, В. Д. Лутченко. М.: ИНФРА-М, 1997. 576 с.

15. Фрейденберг О. М. Миф и литература древности. Екатеринбург: У-Фактория, 2008. 895 с.

16. Abbe, A. (1965) The Plants of Virgils's Georgies. Ithaca: Cornell University Press. 140 p.

17. Andre Jacques (1956). Lexique des termes de botanique en Latin. Paris: C. Klincksieck. 343 p.

18. Daubeny, C. (1865) Essay on the trees and shrubs of the ancients. London: Oxford. $172 \mathrm{p}$.

19. Ernout, A., Meillet, A. (1951) Dictionnaire etymologique de la langue latine. Histoire des mots. Paris: C. Klincksieck. 1409 p.

20. Friedrich, P. (1970) Proto-Indo-European Trees: The Arboreal System of a Prehistoric People. Chicago: The University Press. 200 p.

21. Önnerfors, A. (1956) Pliniana, in Plinii Maioris Naturalem historiam studia, grammatica, critica. Uppsala, Weisbaden. 196 p.

22. Oxford Latin Dictionnary (1968). Oxford: Clarendon press. 2123 p. 
23. Plinii Secundi (1832) Naturalis historiae libri XXXVII. Recensuit et commentariis criticis indicibusque instruxit I. Silig Gothae. Lipsiae: Teubner. 380 p.

24. Sargeaunt, J. (1920) The Trees, shrubs and plants of Vergil. Oxford, B. H. Blackwell, broad street. $167 \mathrm{p}$.

25. Totius Latinitatis Lexicon (1858-1875) / Opera et studio Aeg. Forcellini et in hac editione post tertiam auctam et emendatam a I. Furlaneto. T. I-VII. Prati: Aldianis.

26. Vergili, P. M. (1830) Bucolica et Georgica. Lipsiae: Hahn. CLX, 600 p.

27. Vergili, P. M. (1907) Aeneis / In usu scholarum iterum recognovit O. Ribbeck / Publius Vergilius Maro. Lipsiae: Teubner. 409 p.

28. Walde, A. (1910) Lateinisches etymologisches Wörterbuch. Heidelberg, Carl Winter's Universitatsbuchhandlung. $1044 \mathrm{~S}$.

\section{Tatiana Kompanets VERBAL MEANS OF NATURAL FRAGMENT IMPLEMENTA- TION OF ANCIENT WORLD-VIEW}

Summary. The article deals with the reconstruction of ancient world model on the basis of Latin nouns, denoting evergreen trees. Analysis of lexis extracted from written sources on scientific topics has shown a specific character of language reflection of the world in accordance with natural concepts of ancient Romans.

The purpose of the research is to analyze the constituents of ancient world-view, reflecting in Roman natural lexis, viz dendronyms (tree names). The novelty of this research lies in the analysis of the natural lexis in aspect of ancient language world-view.

The material under consideration gives us the possibility to claim, that semantic structure of Roman dendronyms, their number and peculiarities of functioning reflects the separate fragment of archaic perception, saving information about material culture and mental world of classic society. From one point of view we can track the clear practical sense of usage of wood, tar, turpentine, flavourings; from another point of view - evergreenness shows ethical and moral values, give a possibility to use wreaths, flower-chains, crowns made from evergreen trees for the ritual and emblematic purposes. From genetic point of view there are lexis of indoeuropean, unknown and Roman origin in corpus of dendronyms.

Classic world view is determined as reality, comprised of archaic concepts, reflected in lexis of Latin. Dendronomical segment of classical world view is characterized by different structuresemantic organization. Classical world model reflects common knowledge of tree characteristics, characterized linguistic community of ancient world.

Undoubtedly, the further research of world view structure and their substantional sphere will enlarge the ontological aspect of modern linguistic.

Keywords: concept, conceptual and language world view, national mentality, classical languages, lexis, dendronyms.

Vitae

Tatiana Kompanets

Candidate of Philology, Associate Professor, Associate Professor at the Department of the Romance Languages and World Literatures, Vasyl' Stus Donetsk National University, Ukraine.

Correspondence: t.kompanets@donnu.edu.ua 